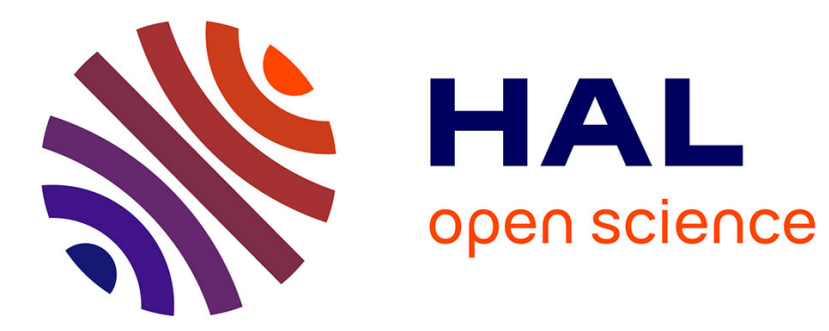

\title{
Regolith weathering through heating samples under reducing conditions for Phobos surface studies
}

\author{
Jeremie Lasue, P.C. Pinet, Michael J. Toplis, Pierre Beck, L. Cao, Pascal
} Munsch

\section{- To cite this version:}

Jeremie Lasue, P.C. Pinet, Michael J. Toplis, Pierre Beck, L. Cao, et al.. Regolith weathering through heating samples under reducing conditions for Phobos surface studies. NASA EXPLORATION SCIENCE FORUM / EUROPEAN LUNAR SYMPOSIUM 9th, Jul 2021, San Francisco, United States. hal-03443035

\section{HAL Id: hal-03443035 \\ https://hal.science/hal-03443035}

Submitted on 25 Nov 2021

HAL is a multi-disciplinary open access archive for the deposit and dissemination of scientific research documents, whether they are published or not. The documents may come from teaching and research institutions in France or abroad, or from public or private research centers.
L'archive ouverte pluridisciplinaire HAL, est destinée au dépôt et à la diffusion de documents scientifiques de niveau recherche, publiés ou non, émanant des établissements d'enseignement et de recherche français ou étrangers, des laboratoires publics ou privés. 


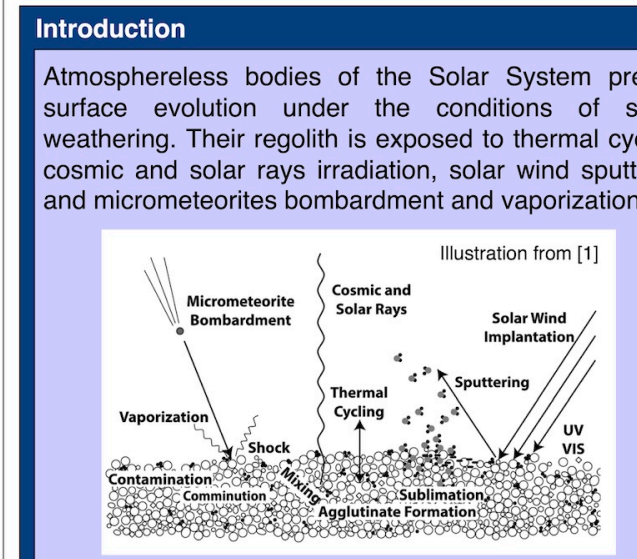

With time, the regolith accumulates optically active opaque particles such as nanophase metallic iron particles on the surity increase in iron particles modifies the spectral properties of the material with a reduced albedo, and absorption bands generally associated with a global reddening of the spectral slope $[1,2]$

Previous studies have shown that nanophase iron particles inducing weathering spectral properties will accumulate at the surface of olivine and pyroxene micrometeorite impacts by pulsed laser [3]

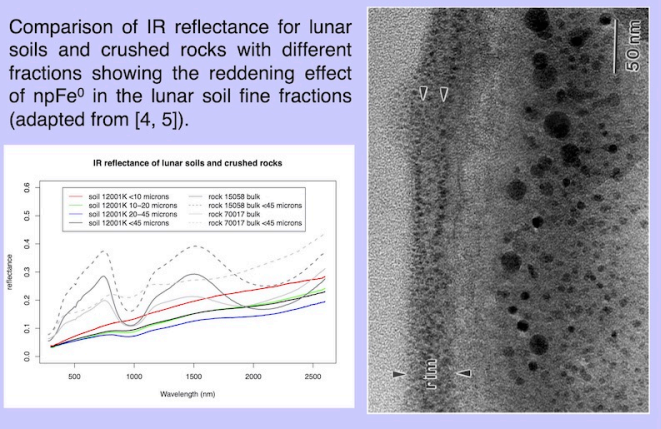

J. Lasue1(jlasue@irap.omp.eu), P. Pinet!, M. Toplis' ${ }^{1}$, P. Beck ${ }^{2}$, L. Cao', P. Munsch'.
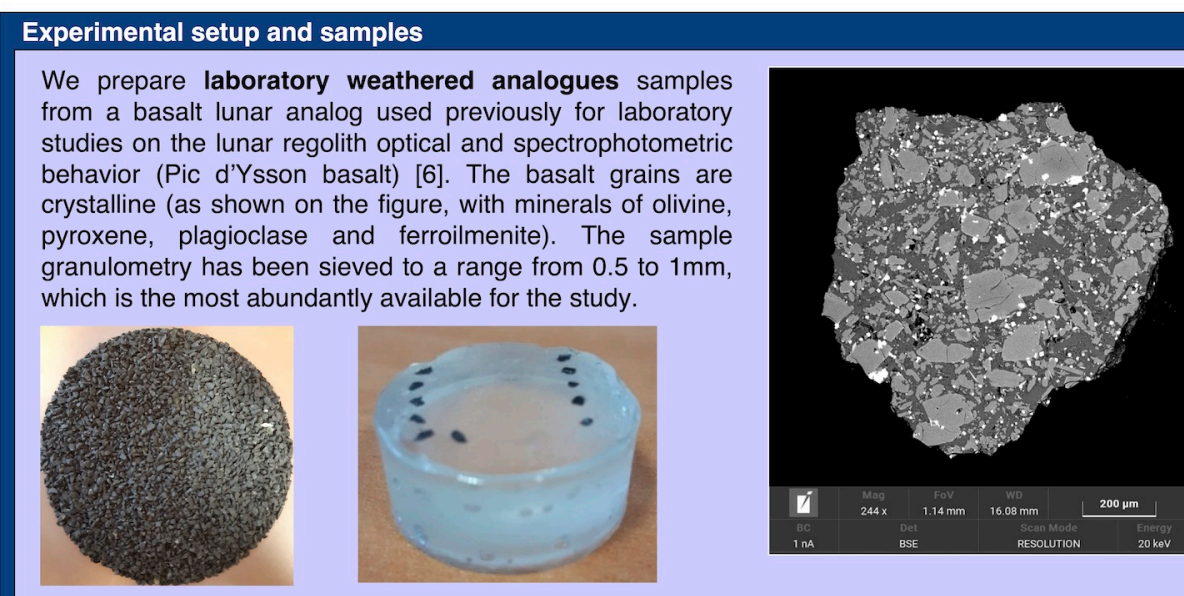

\begin{tabular}{|l|l|l|l|l|l|l|l|l|l|l||}
\hline $\mathrm{SiO}_{2}$ & $\mathrm{Al}_{2} \mathrm{O}_{3}$ & $\mathrm{Fe}_{2} \mathrm{O}_{3}$ & $\mathrm{MnO}$ & $\mathrm{MgO}$ & $\mathrm{CaO}$ & $\mathrm{Na}_{2} \mathrm{O}$ & $\mathrm{K}_{2} \mathrm{O}$ & $\mathrm{TiO}_{2}$ & $\mathrm{P}_{2} \mathrm{O}_{5}$ & $\begin{array}{l}\text { Illustration of the Pic } \\
\text { d'Ysson lunar basalt }\end{array}$ \\
\hline 42.8 & 11.5 & 12.9 & 0.3 & 15.3 & 9.6 & 2.7 & 1.2 & 2.1 & 0.6 & s. \\
\hline
\end{tabular} \begin{tabular}{l|l|l|l|l|l|l|l|l|l|l|}
42.8 & 11.5 & 12.9 & 0.3 & 15.3 & 9.6 & 2.7 & 1.2 & 2.1 & 0.6 & $\begin{array}{l}\text { d'Ysson lunar basalt } \\
\text { analog sample [6] }\end{array}$ \\
\hline
\end{tabular}

The sample is heated to near melting temperature $\left(1000-1100^{\circ} \mathrm{C}\right)$ in an atmosphere controlled

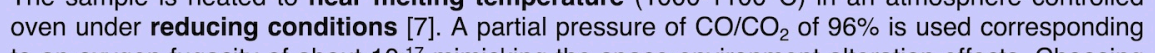
to an oxygen fugacity of about $10^{-17}$ mimicking the space environment alteration effects. Choosing
this fugacity places us well below the Iron-Wustite (IW) buffer curve. The samples are altered for different exposure times ranging from 1 to 8 hours.
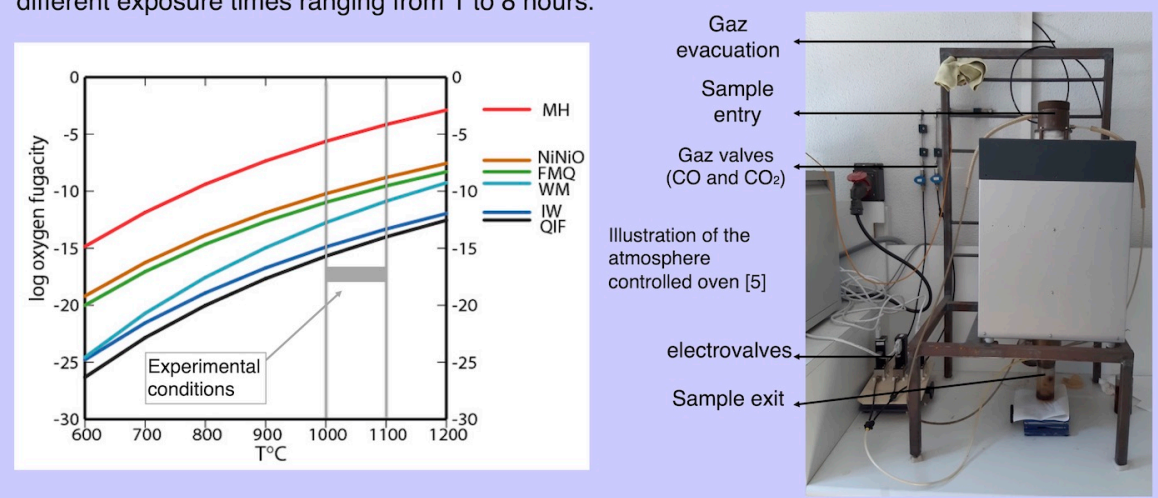

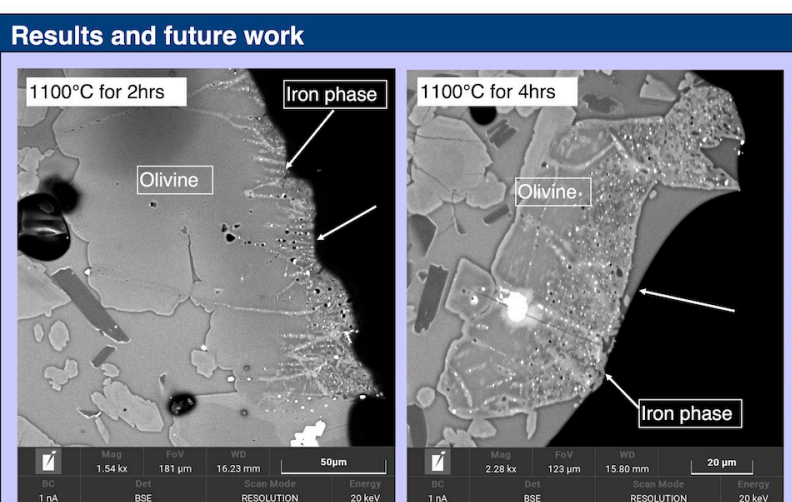

Submicronic metallic $\mathrm{Fe}$ nanophase iron particles $\left(\mathrm{npFe}^{0}\right)$ [8] appear on the surface of the weathered samples analysed with SEM. The thickness varies with the duration of exposure to $1100^{\circ} \mathrm{C}(\sim 10)$ microns for 2hrs, $\sim 20$ icrons for 4 hrs)

iron phase dimensions vary. Nanophase iron is dominant in olivine grains, while pure iron A gran ans of several microns can appear direclly on the surface of basaltic matrix.

A grain altered at $1100^{\circ} \mathrm{C}$ for $8 \mathrm{hrs}$ was analyzed with a scanning electron microprobe (Sxfive Cameca). The iron phase is dominant in the grain, but the Ni / Fe ratio varies indicating that the he of such a process to simulate long-ter
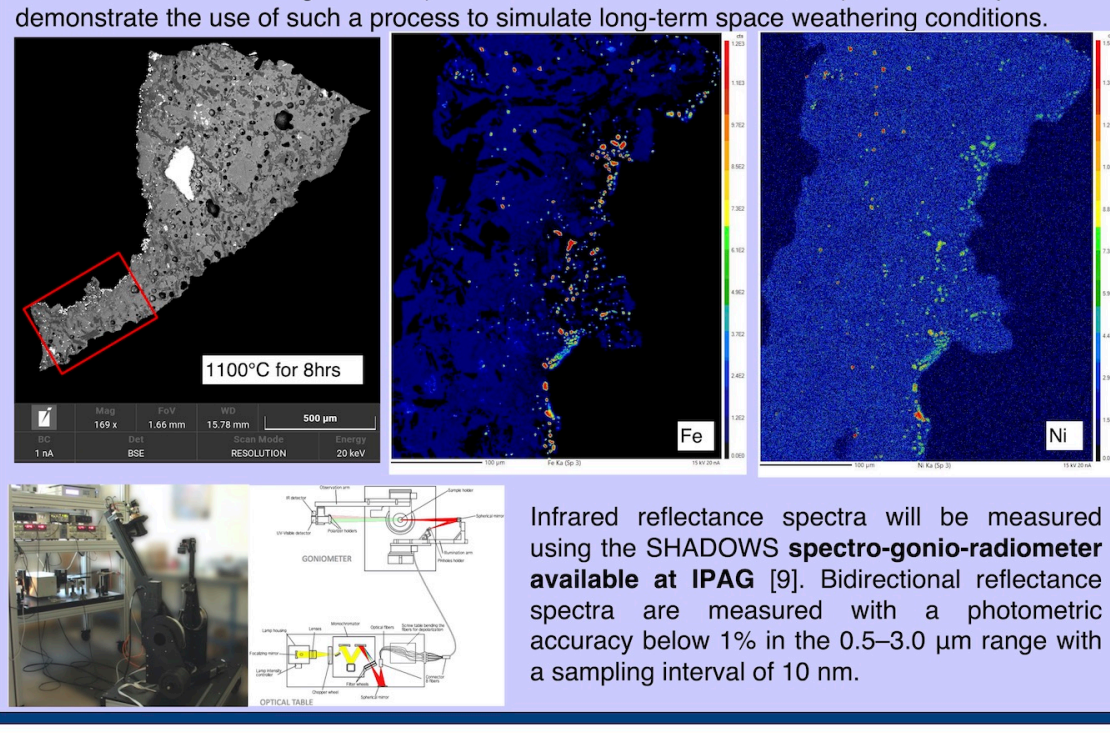

- Analogs for space weathering can be prepared in the laboratory by using short heating under reducing conditions. 